\title{
Političkoekonomske marginalije o recepciji Marxa u XXI. stoljeću (u povodu čitanja knjige Daga Strpića Robna proizvodnja i udruženi rad u Marxovoj kritici političke ekonomije)
}

\author{
BOGOMIR KOVAČ \\ Ekonomski fakultet, Sveučilište u Ljubljani
}

\begin{abstract}
Sažetak
Političkoekonomskom analizom recepcije Marxa u Strpićevoj knjizi o Marxovoj kritici političke ekonomije autor želi pokazati kakav je suvremeni položaj i koja je moguća aktualnost Marxove analize. Do aktualizacije i povratka Marxu uvijek dolazi u vrijeme kriza, njegova intelektualna sudbina ovisi o preobrazbi sadašnjeg kapitalizma i njegovoj alternativi. Paradoks teorijske nedovršenosti u Marxovoj analizi zbog njegove spoznajne težnje za savršenstvom epistemologije kapitalizma postaje sudbina svih marksističkih interpretacija, pa tako i Strpićeve. Problem Marxa danas je upravo u metafizici teorije vrijednosti i cijeloga robnog sustava koji ne omogućuje ontologijske preobrazbe vrijednosti, kapitala i kapitalizma. Njegov teorijski pristup je više fiziokratski nego novčani, više ekonomski nego politički. Zato Bidetova rekonstrukcija Marxa u okvirima moderne polazi od "metastrukture" općega političkopravnog momenta, koji u marksovskoj kritici nedostaje. Primjeren pristup podrazumijeva poimanje kapitalizma kao eminentno političkoga: politički kapitalizam, kako pokazuje autor, nije poseban oblik kapitalizma, nije historijski vezan uz suvremeni oblik kapitalizma XXI. stoljeća (Kina...), nego je njegova univerzalna povijesna forma. Marxova je kritika političke ekonomije moderna upravo na tom nedovoljno određenom putu njegove analize. Politički kapitalizam kao "kapitalizam općenito" pokazuje svoju relevantnost u analizi suvremenih kriza, koje nisu više samo ekonomske nego ekologijske, pa i pandemijske. U nizu recentnih kriza političkog kapitalizma pokazuje se kako smo suočeni s izborom između realnog autokratskog "barbarskog kapitalizma" i više utopijskog "kozmopolitskog ekosocijalizma".
\end{abstract}

Ključne riječi: kapitalizam, robna proizvodnja, kritika političke ekonomije, ekosocijalizam, Marx, Strpić 


\section{Karl Marx, jučer i danas}

Godine 2017. i 2018. bile su pune marksističkih i revolucionarnih obljetnica: od 50 godina od studentskih pobuna 1968. i 100 godina od početka ruske revolucije 1917. godine, preko 150. obljetnice prvog izdanja Kapitala (1867) i 170 godina od proglasa Komunističkog manifesta (1848), sve do 200 godina od Marxova rođenja (1818).

Kakva je danas intelektualna i politička sudbina Marxa, čovjeka koji je bio nesuđeni glavni politički ideolog socijalističkih revolucija i prevrata u XX. stoljeću, teorijskog analitičara koji je lucidno pokazao najdublje antagonizme kapitalističkog društva? Odgovori nisu ni jednostavni ni jednoznačni. Možda najvažnija poanta Marxove suvremene relevantnosti još uvijek ostaje slavna 11. teza o Feuerbachu da su filozofi dosada svijet samo različito interpretirali, međutim radi se o tome da ga se izmijeni. Tu kritičnu točku današnje recepcije Marxa želim ilustrirati kroz četiri uvodne lapidarne napomene.

Prva teza: Godine 1983, uz stogodišnjicu Marxove smrti, prigodne referate o Marxu od Moskve i Pekinga do Beograda održavali su najviši partijski lideri, Andropov u Moskvi, Hu Yaobang u Pekingu, Mitja Ribičič u Beogradu. Godine 2018, u povodu dvjestogodišnjice njegova rođenja, šire bavljenje Marxom ostaje predmetom manje važnih intelektualnih skupova. Izgleda da propast socijalizma u istočnoj Europi poslije 1989, raspadanje Sovjetskog Saveza i uspon neoliberalnog kapitalizma u devedesetima označuju i kraj Marxova epohalnog utjecaja. Čak i kineski komunisti, koji ostaju na vlasti u svom političkom kapitalizmu, više ne traže ideološke referencije u marksističkoj lektiri. U zapadnom svijetu, posebno u Europi, marksistički orijentirane stranke na radikalnoj ljevici potpuno su marginalizirane ili pak više i ne postoje, socijalističke (socijaldemokratske) stranke umjesto marksističke paradigme upotrebljavaju nekakvu sintezu socijalnog keynesijanizma. Spoj Marxa kao teoretičara kapitalizma i radničkog ideologa socijalizma (komunizma) zapravo nikada nije uspio. Komunisti su Marxa politički krivo instrumentalizirali u socijalizmu XX. stoljeća, ali je barem kao teoretičar kapitalizma ostao aktualan i u XXI. stoljeću, posebno poslije financijske i ekonomske krize 2008. godine, pa i sadašnje radikalne ekološke kritike kapitalizma. Ako dakle želimo danas staviti Marxa u povijest izvan mitova, moramo znati baratati mitovima izvan povijesti.

Druga teza: Intelektualna percepcija Marxa uvijek je bila paradoksalna. G. B. Shaw davnih je dana cinično napomenuo da je pročitao prvu knjigu Kapitala kako bi se uvjerio da je nitko drugi nije pročitao. Ali je na drugoj strani za B. Brechta Marx, upravo zbog Kapitala, pa i drugih svojih teorijskih djela, bio jedini pravi gledatelj njegovih predstava, drugi mu nisu bili potrebni. Ako ostanemo kod dviju suvremenih biografija, kao što su djela G. Stedmana Jonesa (Stedman Jones, 2016) ili J. Sperbera (Sperber, 2013), iz njih razaznajemo Marxa kao kompleksnog intelektualca kojega valja smjestiti u okvire XIX, a ne XX. stoljeća. Jednostavne inter- 
pretacije Marxa poput Kautskijeve i Plehanovljeve na jednoj, ili pak kompleksnije čitanje Rubina i Iljenkova, pa Schumpetera i Berlina na drugoj strani, problematične su po svojoj jednoznačnosti. Tek slavni strukturalistički teorijski obrat Althussera i Balibara otvara epistemologijske okvire za novo čitanje Marxa, da bi na kraju M. Foucault Marxa nazvao ključnim osnivačem diskurzivne teorijske analize moderne. J. M. Keynes smatrao je da Marx zbog svojih teorijskih pogreški nije relevantan za suvremenu ekonomiju, P. Samuelson ga kasnije iz aspekta čiste ekonomske teorije svrstava među hegelijanizirane postrikardovce. Međutim T. Piketty upravo preko Marxa dolazi do sadržajne analize suvremenog kapitalizma u svojoj knjizi Kapital XXI. stoljeća (2013). U proljeće 2018, na skupu centralnih bankara u Torontu M. Carney, tadašnji guverner Bank of England, citirajući Kaleckog i Minskyja, spominje upravo Marxa koji nam nedostaje u razumijevanju suvremene financijske krize. Kaleidoskop recepcija Marxa na različitim razinama zapravo nema granice. Na kraju još jedna ilustracija: na aukciji knjiga slavne kuće Döbritz u Frankfurtu 2017. godine Marxov Kapital I prodan je za 200.000 eura. I to bi danas mogla biti tržišna vrijednost Marxa.

Treća teza: U političkoj ekonomiji socijalističke Jugoslavije, koju uzimam kao staru domaću referenciju za različite percepcije Marxa, knjiga Daga Strpića Robna proizvodnja i udruženi rad u Marxovoj kritici političke ekonomije zapravo je posljednji veliki pokušaj analize Marxova opusa. Riječ je o doktorskoj disertaciji na kojoj je Strpić radio gotovo dvadeset godina. Disertacija je bila obranjena 1991. godine u Zagrebu, čime je na najbolji način zaključena epopeja velikih radova jugoslavenske političke ekonomije na tragu Marxa. Počela je u pedesetim godinama sjajnim i za ono doba izuzetno kontroverznim doktoratom Aleksandra Bajta (Marxov zakon vrijednosti, 1953) i završila Strpićevim kritičkim čitanjem Marxa i njegove političke ekonomije. Od Bajta do Strpića velika je transformacija u čitanju Marxa, najprije kao teoretičara vrijednosti i cijena, a na kraju više kao sustavnog teoretičara tržišnog društva i kritičara znanstvenih paradigmi. Preduvjet upotrebe Marxova kategorijalnog aparata bila je i ostala rekonstrukcija njegovih sistemskih djela, ne samo Kapitala nego i Grundrissa i Teorija o višku vrijednosti. Međutim Strpić ide i dalje od toga, smjera rekonstruirati Marxov istraživački put u cjelini, pa zato kao politolog i ekonomist analizira Marxa posredstvom pomnog čitanja Smitha, Hobbesa, Hegela i drugih klasika. To je bio izuzetan pristup, neviđen u jugoslavenskoj političkoj ekonomiji, što Strpića u tom pogledu izdvaja iznad svih. Kada su Marx i marksizam bili ideološki poraženi političkim raspadom Jugoslavije i samoupravnog socijalizma, stigli smo dakle sa Strpićem na njegov lokalni intelektualni Olimp.

Četvrta teza: Na kraju, još jedna uvodna napomena o Marxu i Strpiću posebno, o njihovim neobičnim zajedničkim crtama, koje dobro ilustriraju različita intelektualna prepletanja suvremenih teorijskih marksističkih analiza i Marxove ostavštine. 
Kao što znamo, Marx je planirao šest tomova Kapitala, danas imamo tri knjige, sam je stigao da napiše samo prvu, a pripremni su mu radovi izuzetno inspirativni i obimni (Grundrisse, Teorije o višku vrijednosti). I ova Strpićeva studija ima tri knjige, šest dijelova i šesnaest poglavlja, polovina studija su pripremni radovi, u kojima poput Marxa kritički analizira teorije Smitha, Hobbesa, Hegela... Marx svoju kritiku političke ekonomije kapitalizma nije izveo do kraja, nego ostaje u metodologijskim bravurama analize i interpretacije kapitala. I Strpić primjenom Marxove kritike političke ekonomije na analizu socijalističke robne proizvodnje, slično Marxu, ostaje najviše na teorijsko-metodološkoj razini. Taj Marxov paradoks teorijske nedovršenosti u težnji za savršenstvom postaje sudbina suvremenog marksizma, pa tako i Strpića, i ne samo njega. Zato na kraju dolazimo do stajališta da treba najprije čitati Marxa da bismo uopće razumjeli intelektualnu sudbinu suvremenih marksista, a ne obrnuto. Ali na kraju svaka moguća aktualizacija Marxa danas ovisi upravo o revitalizaciji marksističke teorije, ako za taj projekt još postoji intelektualni i političkoekonomski interes.

Ono što od Marxa ipak preostaje pomalo je biblijski teorijski kriticizam u njegovoj "kritici političke ekonomije". Marx je još od svoje disertacije u ranim godinama pokazao izuzetnu političku energiju i teorijsku hrabrost, bio je vjernik pravednog društva i historijskog poslanstva radničkog pokreta, koji nikada nije želio shvatiti bez kritičke distance, ali je na kraju i sam postao dio njegovih i svojih ideoloških i političkih zabluda. Zato su svi kasniji "marksizmi” djelovali tako groteskno kada su se petljali u dogmatske interpretacije Marxa ili pak nikada dovršene priče kako ga treba čitati i teorijski upotrijebiti u analizi suvremenih društvenih zbivanja. Baš ovo posljednje pitanje, što zapravo može danas nama ponuditi njegov teorijski analitički aparat, postalo je dio one famozne "marksističke renesanse" (1960-1990), posebno u okvirima zapadne kritičke društvene teorije. To je i razdoblje najveće intelektualne afirmacije Marxa u XX. stoljeću.

Izgleda da mogući povratak Marxu (njegova aktualizacija) uvijek dolazi u vrijeme velikih kriza, financijskih, ekonomskih, političkih i kulturnih, sada i civilizacijskih, jer kapitalizam je došao do krajnje ekološke krize planeta. Svijet kapitalizma, kako ga slika Marx, jest društvo u kojem prevladavaju materijalni odnosi nad ljudima, društveni odnosi nastaju između stvari (roba) na tržištima, cirkulacija kapitala (novca) postaje društvena samosvrha, subjekt sistema nije više čovjek, nego kapital. Nema velike dvojbe o tome da je Marxova analiza kapitalizma danas relevantnija od bilo koje političkoekonomske teorije XIX. stoljeća. Raspad socijalističkih država u tom pogledu za Marxa i njegovu suvremenu recepciju nije presudan. Marx nikada nije dublje analizirao društva istočne Europe, poput Rusije i Kine, njihov socijalistički put brze industrijalizacije bio je izvan njegove teorijske analize. Zato proglašavati Marxa za ideologa socijalističkih eksperimenata radikal- 
nih komunističkih pokreta ostaje jednako pogrešno kao vezivati njegovu intelektualnu sudbinu uz nužnu propast kapitalizma. Marx je zapravo zaslužan da danas ipak postoji ideja da je moguća alternativa kapitalizmu. Bez Marxa kapitalizam naprosto postaje permanentnom političkoekonomskom formom društva za sva vremena. To je ona karika neoliberalne paradigme, čuveni "kraj povijesti" (Fukuyama), da alternative zapravo nema, jer više nije ni potrebna.

\section{Neki teorijski problemi moguće rekonstrukcije Marxove kritike političke ekonomije}

Povratak Marxu kao načinu političkoekonomske analize započinjemo Strpićevim fundamentalnim čitanjem i analizom Marxove kritike političke ekonomije, usporedivim s izuzetnom Bidetovom analizom u Što da se radi s "Kapitalom”? (Bidet, 1988). S posebnim osvrtom na njihov mogući teorijski dijalog, ne samo u prvoj fazi nego i u vezi s Bidetovom kapitalnom knjigom Opća teorija moderne, na što je upozorio politolog D. Lalović (Lalović, 2008, 2017; vidi i Kovač, 2009), prevodilac Bideta i urednik ove Strpićeve studije (Bidet, 2008; Strpić, 2017). Strpićeva osnovna namjera je bila postaviti teorijski okvir za analizu robne proizvodnje u socijalističkom društvu, spojiti pojam udruženog rada s konceptualizacijom tržišnog društva kroz Marxov analitički aparat robe i tržišta općenito. Nasuprot ekonomistima, kao što je primjerice Miladin Korać, koji je želio postati jugoslavenski Marx, a svojim obimnim djelom Samoupravni način proizvodnje u čak tri knjige (Korać, 1977) ponudio jednostavno pomicanje apstraktnih modela robne proizvodnje i teorije vrijednosti u okvire primarno ideološki postavljenih samoupravnih odnosa, njegov je naum bio direktno prenijeti Marxov način rezoniranja iz Kapitala na samoupravno društvo. Robnoj proizvodnji je ekonomska vrijednost imanentna, zato je glavni zadatak kroz teoriju vrijednosti doći do "socijalističke" normalne cijene. Time bi se pokazalo i dokazalo da je moguć poseban spoj robne proizvodnje i socijalizma (socijalistička robna proizvodnja). Naravno, jednostranosti takve redukcije Marxove analitičke metode i normativnoga modelskog deduktivizma time su došle do granica teorijskog apsurda, gdje je kapitalistički način proizvodnje teorijski usporediv sa samoupravnim, dok dinamika proširene reprodukcije ovisi o padu prosječne profitne ili pak dohodne stope (Kovač, 1984).

Grupa mlađih politekonomista, poput Strpića, išla je drugim putem. Ključ problema vidjeli su u metodi istraživanja i izlaganja kod Marxa, da bi tim pristupom onda došli do primjerene instrumentalizacije marksističke teorije u konkretnim uvjetima tadašnje Jugoslavije. Naime, da bi se teorijski moglo shvatiti "socijalističku robnu proizvodnju", bilo je potrebno ponajprije razumjeti upravo socijalistički politički normativni okvir i institucionalnu teoriju robne proizvodnje (tržišta). Nekritička jugoslavenska marksistička politička ekonomija smatrala je da 
su socijalistički odnosi pretpostavka robne proizvodnje i presudne transformacije tržišta u "socijalističko samoupravno tržište" (teza dohodaša, poput Koraća). S druge su strane drugi politekonomisti u spoju neoklasične i marksističke ekonomske teorije smatrali tržište (i robnu proizvodnju) institucionalno neutralnim sredstvom, iz čega su zaključivali kako u socijalizmu takva "ekonomska mašina" jednostavno reproducira prevladavajući historijski oblik (socijalističkog) sistema (teza profitaša, poput Bajta). Ako je tržište podređeno socijalističkim normativnim odnosima ili pak djeluje kao društveno neutralan mehanizam, posljedice su jednake - socijalističko tržište ili socijalistička robna proizvodnja nije određena vlastitom (kapitalskom) institucionalnom strukturom. Paradoks nije toliko u "robnosti" socijalističkih proizvodnih odnosa, nego u "socijalističkosti" tih proizvodnih (političkih) odnosa. Čitava marksistička paradigma, ne samo politička ekonomija, nije odgovorila na jednostavno, ali bitno pitanje koje je polazište svih teoretizacija - što je zapravo socijalizam? Drugim riječima, ne može apriornost normativnih, ideologijskih socijalističkih odnosa određivati domašaj tržišnih institucija, nego obrnuto. Robna proizvodnja, tržišne institucije, određuju mogućnosti razvoja i sadržaj "socijalističkih" odnosa (sistema). I upravo u tom kontekstu valja promišljati kritiku političke ekonomije socijalizma u Marxovu smislu, na koji se referiramo u daljnjoj analizi (Kovač, 1988).

Proizvodnja je u klasičnoj političkoj teoriji i političkoj ekonomiji osnova svega, time počinje Marx, a s njime i Strpić. Proizvodnja i rad temelj su reprodukcije društva, pri čemu politička teorija spoznaje logiku moći i reprezentacije interesa. Smith i Hobbes su na tom putu ključni, pa Strpić zapravo utvrđuje hijerarhiju njihove važnosti za Marxa i za svoju rekonstrukciju marksovskog pristupa robnoj proizvodnji. Strpićeva prva knjiga u ovoj studiji (str. 25-102) završava Marxovom spoznajom iz Priloga kritici političke ekonomije (1859) da "način proizvodnje materijalnog života uvjetuje proces socijalnog, političkog, duhovnog života uopće" (Strpić, 2017: 48). Druga knjiga polazi zato od političkoga i ekonomskog razumijevanja vrijednosti, opet kroz teorijsku rekonstrukciju klasika (str. 103-218). Trijada cijena, vrijednost i vrednota, od ekonomije do političke kulture, zapravo je put rekonstrukcije građanskog (trgovinskog) društva kroz način proizvodnje vrijednosti. Spoznaja da je način proizvodnje društva zapravo način proizvodnje vrijednosti ključ je Marxove teorije, zato roba i robna proizvodnja dolaze na početak istraživanja i izlaganja kapitala. Dvojstva roba i rad, roba i novac, roba i način proizvodnje predstavljaju logične krugove njegova teorijskog modela. Marx 1857. godine piše kako se poslije 10 godina vraća kritici političke ekonomije, i tu ostaje do kraja života. Strpić čini pomalo isto, tek 10. poglavlje druge knjige (na 183. stranici) dolazi do vrijednosti koja "procesira". I tek je taj proces pravi početak željene rekonstrukcije Marxa, kao dobar primjer suvremene konstrukcije marksističke teorije. 
Treća Strpićeva knjiga razotkriva suštinu problema (str. 219-338). Ako želimo spojiti robnu proizvodnju koja ima imanentno kapitalistički karakter (robna proizvodnja i građansko društvo) sa socijalističkim proizvodnim odnosima, potrebne su nam dovoljno apstraktne definicije robe i kapitala. "Roba općenito" i "kapital općenito" su te "bogate" teorijske apstrakcije koje mogu dovesti do različitih načina proizvodnje kao kombinacije apstraktne teorijske konstrukcije i historijskih intervencija. Marx dugo promišlja kako početi u Kapitalu, zna da ne smije započeti konkretnom historijskom analizom (jednostavnom robnom proizvodnjom), nego teorijski apstraktnom. Bogatstvo roba je bogatstvo građanskog društva, roba je njegov elementarni oblik, koji možemo shvatiti kao "robu općenito". Iza toga stoji i rad, "rad općenito", "forma vrijednosti općenito", "kapital općenito". Univerzalna forma vrijednosti je ključ razumijevanja njezine transformacije u cijene. Tek tada može doći do njezine tranzicije iz jednostavne u razvijenu, iz kapitalističke u socijalističku robnu proizvodnju.

Problem teorijske konstrukcije ovdje je dakle povezan s Marxovom teorijom vrijednosti, koja se oduvijek smatra znanstvenom jezgrom njegove teorije kapitalizma. Taj je pristup međutim teorijski izuzetno prijeporan. Marx naime određuje vrijednost $u$ okviru analize rada uopće $u$ proizvodnji, ali govori ujedno i o razmjenskoj vrijednosti i cijenama. Ako je rad materijaliziran u proizvodu, to samim time ne znači da je proizvod postao roba, rad stvara vrijednost samo in potentia, koja se realizira tek u razmjeni. Zato vrijednost roba ne objašnjava proizvodnja, nego razmjena sa svojim cijenama, vrijednosni sadržaj ne određuje rad, nego novac kao prava inkarnacija društveno potrebnog apstraktnog rada, "rada općenito". Tek onda kada "rad općenito" može komunicirati kao "kapital općenito", vrijednost roba postaje kroz višak vrijednosti kapital. Strpić dolazi do tog problema. Procesiranje vrijednosti polazi od robe kao početnog momenta kapitala, ali obrnutim putem izlaganja. "Kapital općenito" stoji kod Strpića ispred "robe općenito". Tako je, slijedeći Marxa, došao do krajnjeg ruba Marxove teorijske konstrukcije robnog načina proizvodnje u "idealnom presjeku". Naime, robna forma vrijednosti postoji kada je roba općenita, univerzalna, totalna. Tek onda može rad sadržan u robi postati "općeniti rad".

Što je onda početak, što određuje robu i njezinu vrijednost? Tržište, rad, novac ili riječ (ugovor)? Marx to nikada nije do kraja riješio. Ako je roba inkarnacija rada, onda je novac kod Marxa inkarnacija općeg rada. Opća forma vrijednosti je prema tome nešto treće, ne roba i ne rad, nego novac koji poprima izvorno metafizički karakter. Trijada apsolutna ideja = apstraktni rad = novac postoji kao stvarna inkarnacija apstraktnog rada. Pojam vrijednosti je forma vrijednosti, forma vrijednosti proizlazi iz pojma vrijednosti. Na početku je bila riječ, riječ je Bog, čitamo u Bibliji. Svijet robe je prema tome svijet metafizike, dijalektička logika je zapravo 
spekulativna logika. Ontologija robnog svijeta je u biti teologija robe, rada i kapitala općenito.

Problem s kojim se susreće Strpić, čitajući Marxa, nije zapravo u određenoj teorijskoj redukciji, nego u Marxovoj teorijskoj produkciji, u njegovu modelu robne proizvodnje i kapitala općenito. Međutim čitava ta metafizika robnog sustava naprosto ne omogućava ontologijske transformacije, što je problem koji nije dobro shvatio ni Bidet u svojoj čuvenoj rekonstrukciji Marxa kroz opću teoriju moderne (Kovač, 2018: 230). Nijedna apstraktna rekonstrukcija robne proizvodnje općenito ne može dovesti do konkretne historijske ontologije robne proizvodnje kroz procesiranje prijelaznih formi. Ta političkoekonomska transformacija može se učiniti samo skokom, radikalizacijom političkih prevrata, a ne evolucijskim ekonomskim promjenama ("probojne točke" diskontinuiteta u Marxovoj trećoj knjizi Kapitala). Marx govori o formi totalnog ekvivalenta, pri čemu totalno može postati i totalitarno, ekonomski proces dolazi do nužne točke političkog prevrata. Zato se kod Marxa uvijek nanovo miješa teorijska analiza u Kapitalu s političkim aktivizmom.

Kad Strpić dospijeva do kraja svoje analize, u 15. i 16. poglavlju, uočava da teorijska konstrukcija nema izlaza, da je nemoguće procesirati dijalektičko oposebljenje od apstraktne na konkretnu razinu, metafizika ne može postati društvena fizika. Marx nije nikada završio Kapital ne zbog toga što nije stigao, nego zato što nije mogao. Kapitalizam se već u godinama pisanja Kapitala promijenio, a danas bi teorijska rekonstrukcija na Marxovu putu bila još kudikamo teža. Strpić prema istoj matrici ostaje u metodologijskim bravurama, njegova knjiga završava na mjestu gdje bi trebala zapravo početi. Zato je pri pisanju disertacije promijenio istraživački plan. Ne radi se više o teoretiziranju robne proizvodnje i udruženog rada, nego više o velikoj analizi nastajanja Marxove kritike političke ekonomije. To nije teorijski poraz, nego jedini mogući izlaz. Priznanje teorijskog poraza u marksizmu znači zapravo pobjedu, da možete staviti povijest izvan mitova, a ne da mitovi postaju dio naše povijesti.

Marxova teorija vrijednosti dokazuje kako je eksploatacija radnika u proizvodnom procesu potreban uvjet za "proizvodnju" profita, a politička dominacija vlasnika proizlazi iz privatnog vlasništva, pravnog sustava autokratskih država i na temelju kapitala. "Udruženi rad" je zapravo institucionalni ugovor, ne više ideologijska konstrukcija, nego pravni sustav na kojemu se temelji "robna proizvodnja" tržišne ekonomije. Marx je ovdje anticipirao institucionalno rješenje koje je kasnije ponudila neoklasična ekonomija: odnos agenta i principala u teoriji firme i ograničena konkurencija na tržištu roba i radne snage (Vrousalis, 2013). Marx nije objasnio zašto su radni uvjeti i ugovori između radnika i poslodavaca nekompletni, zašto na razini firme ne funkcionira logika tržišta, nego moć kapitala, zašto tržišta ne funkcioniraju kroz slobodnu konkurenciju, ali je zato anticipirao politički okvir 
mikroekonomske teorije (despotizam radnog mjesta, politiku produkcionih odnosa na mikro i makro razini).

Coase je sedamdeset godina kasnije definirao odnose u firmi kao politički pravni ugovor radnika i vlasnika kojim se transferiraju kontrolna prava u proizvodnom procesu na menadžera u razmjeni za plaću, a transakcijski troškovi nisu ekonomski, nego politički oportunitetni troškovi hijerarhijske organizacije. Poduzeće je kontrapunkt tržišnim odnosima (Coase, 1960). Alchian i Demsetz su na osnovi Coaseove ideje zaključili da je poduzeće, osnovna ćelija tržišnog sistema, zapravo "komandna ekonomija" (Alchian, Demsetz, 1972). Lerner o tome kaže kako taj institucionalni okvir pretvara politički problem u ekonomsko rješenje, ekonomske transakcije rješavaju pitanje političke dominacije na razini firme, potrošačkog suvereniteta na političkoj razini države (Lerner, 1972). Demonstracija (političke) moći zapravo je temelj konkurentskog djelovanja tržišne ravnoteže. Marx je u svojoj kritici političke ekonomije anticipirao upravo tu promjenu "kapitalističkog načina proizvodnje unutar samog načina proizvodnje", politički sustav u procesu proizvodnje je temelj ekonomske dominacije u kapitalističkom tržišnom društvu (Kovač, 1988: 147). Ne može se demokratizirati i liberalizirati kapitalizam dok se ne demokratiziraju radni uvjeti i ne uspostave ravnopravniji uvjeti raspodjele. Ekonomska demokracija je uvjet političke, a ne obrnuto.

Marx je u okviru svoje kritičke političke ekonomije otvorio prostor za razumijevanje političkog kapitalizma. Politička ekonomija socijalizma na tom mjestu griješi u dva navrata. Prvo, zato što svoju ideologijsku perspektivu nasilno preobražava u ekonomski institucionalni sistem, i drugo, zato što sustavno zanemaruje političke okvire mogućeg reformiranja kapitalizma. Naša polazna teza želi pokazati upravo taj krucijalni karakter kapitalizma u XX. stoljeću. Kapitalizam nije ekonomski propao zbog političkih intervencija, prepletanje ekonomskih i političkih interesa osnova su njegove reprodukcije. Politički kapitalizam je u tom pogledu ekonomski sistem u kojem ekonomske i političke elite putem institucionalnih aranžmana na mikroekonomskoj razini firme i na razini makroekonomije tržišnih sustava maksimiraju svoje koristi. Ekonomske elite utječu na političke nosioce ekonomskih politika države da reguliraju tržišta, porezne obveze i budžetsku potrošnju javnih sistema, dok političke elite koriste njihovu ekonomsku podršku na izborima gdje se reproducira njihova moć. Takva razmjena na političkoekonomskom tržištu zapravo je samo drugi način funkcioniranja suvremenih liberalnih demokracija. Politički kapitalizam takvog tipa danas je u različitim institucionalnim modifikacijama razvijen u SAD-u, Putinovoj Rusiji, pa i sadašnjoj Kini, ako ostajemo u okvirima hijerarhije najvećih država svjetskoga kapitalističkog sistema. U Europi je taj tip kapitalizma nastao najprije u korporativističkim ekonomijama nacističke Njemačke i fašističke Italije. Poslije II. svjetskog rata regulirani je kapitalizam postao spoj socijalnog 
keynesijanizma (socijalna država) i liberalne demokracije. Danas je u okvirima globalne neoliberalne paradigme doveo do sve češćeg populističkog prožimanja menadžerskih interesa korporacija i stranačkih oligarhija (Rodrick, 2018).

$\mathrm{Na}$ mogućnost da politički kapitalizam zamijeni onaj tržišni upozorava Holcombe (Holcombe, 2018), međutim za njega je politički kapitalizam zapravo ortački kapitalizam. Politički kapitalizam pak možemo vezati uz polazišnu Weberovu interpretaciju ili pak uz Marxovu kritiku političke ekonomije, što Holcombe u svojoj teorijskoj konceptualizaciji nije elaborirao, nego polazi od analize prepletanja poslovnih elita i političkih interesa u okviru američke demokracije. Takve teze razvijaju i drugi (recimo Stiglitz, Stockman i Lewis), koji pokazuju kako na političke odluke utječu poslovne elite koje zapravo postavljaju pravila igre, a ne obrnuto (Stiglitz, 2019; Stockman, 2012; Lewis, 2013). Američki povjesničar Kolko je u svojoj analizi američkog konzervativizma ukazao upravo na taj povijesni moment američkoga "korporativnog liberalizma". Radi se o političkoekonomskoj kolaboraciji korporativnih i stranačkih elita u okviru uspona američkog konzervativizma 1900-1916, pa onda i New Deala u tridesetim godinama, a u isti okvir možemo smjestiti i čitavo razdoblje Hladnoga rata (1947-1962); kasnije sve to vidimo i u neokonzervativnoj revoluciji Reagana i sadašnjeg neoliberalizma (Kolko, 2009). Međutim politički kapitalizam nije nekakav poseban oblik kapitalizma (Holcombe), ne radi se o njegovoj devijaciji (Lewis), problem nije u konfliktnim odnosima dva kapitalizma, liberalnoga i političkoga, kako misli Milanović (Milanović, 2019). Politički kapitalizam ne postoji ni u postsocijalističkim uvjetima, gdje se još uvijek reproducira državni monopol u tržišnoj ekonomiji (Lazić, 2011), nije ni politička slika tranzicijskoga klijentelističkog kapitalizma (Cvijanović, Redžepagić, 2011).

Na tom se mjestu treba vratiti Polanyiju i njegovoj tezi o strukturi liberalnog kapitalizma i njegovu razvoju. Kapitalizam povezuje različite tipove tržišta, barem tri pokazuju svojstva koja nisu svodljiva na obične konkurentske tržišne uvjete (tržište rada, novca i prirodnih dobara). Zato je moguće kretanje kapitalističkih struktura prema samoregulatornom tržištu ili prema državnoj regulaciji, ali to ne znači da između tih koordinacijskih mehanizama postoji nekakva institucionalna supstitucija, hijerarhija ili čak subordinacija. Suprotno tome, svako tržište zapravo institucionalno povezuje jedno i drugo, radi se o komplementarnosti tih institucionalnih aranžmana. To jednostavno znači da više "tržišta" (konkurencije) znači i više "države" (regulacije), više liberalne demokracije znači i veći stupanj političkog intervencionizma i manipulativnog političkog populizma. Čuveni pasus iz Polanyijeve Velike preobrazbe polazi upravo od te postavke da je liberalna tržišna ekonomija proizvod državnog (političkog) inženjeringa, a nipošto spontanog razvoja. "Laissez-faire je bio planiran; nije bilo tako glede planiranja" (Polanyi, 1999: 167), kapitalizam je više politički oktroiran, dok je "socijalizam" (planska ekonomija) više rezultat ne- 
planiranih historijskih prilika (isto djelo). U tom svjetlu liberalni kapitalizam u svim svojim oblicima od samog početka nastupa kao politički kapitalizam. To znači da politički kapitalizam nije poseban oblik kapitalizma, nego prevladavajući oblik kapitalizma, nije historijski vezan uz suvremeni oblik kapitalizma XXI. stoljeća (Kina...), nego je njegova univerzalna povijesna forma.

U modernom društvu kapital i tržište, poduzeće i država imanentno su povezane institucije, u punoj međuovisnosti. Mi ne živimo u "tržišnoj ekonomiji”, nego u "kapitalističkoj ekonomiji”, u relaciji između tržišta i kapitala smještena je država: analiza tržišne vrijednosti i kapitala po svom je karakteru i ekonomska i društvena i politička. Suština i aktualnost Marxove političkoekonomske analize kapitalizma upravo je u tome da ekonomsku bit upisuje u društvene procese, da pokazuje bitnu neodvojivost ekonomskoga i političkoga u samom karakteru robne proizvodnje, kapitalističke robne proizvodnje i samog tržišnog kapitalističkog društva. Za Marxa je u pojmovima robe, novca i kapitala bitna upravo ta društvena, ekonomsko-politička supstancija, nešto što je tržišnom društvu imanentno, supstancijalno. Bidet je u svojoj analizi došao upravo do te Marxove izvorne pozicije koju naziva, na način Rawlsova "izvornog položaja”, općom “metastrukturom” moderne (Bidet, 2008). Tako stara dilema između logičkog i povijesnog čitanja Kapitala, odnosno o tome kako razumjeti slavnu polaznu točku logike robne proizvodnje, zadobiva sada političkoekonomsko, pravno organizacijsko, regulacijsko rješenje. U tom kontekstu politički kapitalizam postaje dio te teorijske sinteze. Iza političkog kapitalizma stoji cijela logika kapitala i geneza kapitalizma.

Ako sada ostanemo kod prilično pojednostavljene konceptualizacije kapitalizma kroz Marxovu dualnu strukturu kapitala i rada, tada su na jednoj strani društveni odnosi alijenacije i eksploatacije (tržište rada), a na drugoj ekonomski odnosi poduzetništva, bankarstva i financija (tržište kapitala). Međutim tržištu rada i kapitala potrebni su određena funkcionalna struktura, regulacijska pravila, politički institucionalni okvir za njegovo djelovanje. Tržišne institucije pretpostavljaju različite pravne ugovore i moralne norme, što nas nužno vodi do političke strane tržišnog društva, do političke i pravne države. Taj političkoekonomski trokut (tržište, država, moralne norme), na koji je najbolje upozorio Hayek, znači nužno povezivanje svih temeljnih institucionalnih (pravnih, političkih) i funkcionalnih (tržišnih, ekonomskih) karika kapitalizma. Epistemologijska osnova tog trokuta, polazimo li od Marxa, zapravo je djelovanje "robe općenito" i "kapitala općenito" (Marx) na jednoj strani i posebno poimanje Bidetove pravnopolitičke "metastrukture" ("prava općenito") na drugoj. Taj idealni presjek kapitalizma - "kapitalizam općenito" (Marx to naziva "idealer Durchschnitt") jest upravo politički kapitalizam. Premda Marx nije izravno ukazao na tu dimenziju, njegov epistemologijski konstruktivizam u kritici političke ekonomije može voditi do nove analize suvremenog kapitalizma. Marxov doprinos je, 
prema tome, $\mathrm{u}$ epistemologiji političkog kapitalizma. Zato se u vrednovanju njegove kritike političke ekonomije ne radi toliko o pitanjima ekonomske destrukcije kapitalizma koliko o problemima njegove političke reprodukcije.

\section{Marx i novi kapitalistički povratak u budućnost}

Dilema u pogledu aktualnosti Marxove teorije nadasve ovisi o interpretaciji značenja i dometa njegove apstraktne teorijske analize "kapitalizma općenito". Marx svoju teorijsku analizu kapitalizma nije stigao dovršiti u Kapitalu, zbog toga relevantnost tog tipa analize ponajviše ovisi o tome kakva će biti povijesna sudbina kapitalizma u XXI. stoljeću: vode li njegovi antagonizmi u permanentnu krizu i transformaciju prema novom društvu, što je jedna od Marxovih bitnih političkoekonomskih teza, ili pak suvremene ekonomske krize kapitalizma ostaju dio njegove normalne političke reprodukcije? Nadalje, ako krize kapitalizma empirijski postaju sve češće i žešće upravo u Europi kao povijesnom centru kapitalizma (Kindleberger, 2005; Berend, 2006), jesu li danas za globalno kapitalističko društvo opasniji klasični ciklusi i financijsko-ekonomske krize ili pak neke druge sistemske krize (Felton, Reinhart, 2008) izvan neposrednih političkoekonomskih razmatranja (ekološke, pandemijske... krize)?

Za Marxa je u četrdesetim godinama XIX. stoljeća, u okviru revolucionarnih zbivanja 1848, najvažnije bilo socijalnoekonomsko pitanje radnika i političke destrukcije kapitalizma (Komunistički manifest). Kasnije pak glavnu pozornost usmjerava na teorijsku analizu ekonomskog funkcioniranja kapitalizma i različite načine njegove samodestrukcije i transformacije (Grundrisse, 1857-1858; Prilog kritici političke ekonomije, 1859; Kapital, 1867). Marxova kritika političke ekonomije želi kroz teoriju radne vrijednosti, teoriju pada profitne stope i teoriju akumulacije kapitala pokazati osnovnu društvenu nejednakost i mogućnosti transformacije kapitalizma. Marxova analiza nije toliko teorija permanentne krize kapitalizma koliko teorija njegove antagonističke transformacije. Pritom ključne karike tog prijelaza nisu u sferi raspodjele i nejednake razmjene, nego u sferi proizvodnje i potrošnje, ali izgleda da za kapitalizam krajem XX. stoljeća nije toliko koban međuodnos kapitala i rada koliko međuodnos čovjeka i prirode, dakle ne način proizvodnje kapitala, nego način potrošnje prirodnih resursa.

Marx nije izravno pokrenuo pitanja ograničenosti prirodnih resursa, kapitalistički način proizvodnje jest ovisan o materijalnim uvjetima, ali time nije ograničen, granica kapitalizma zapravo su proizvodni odnosi, a ne proizvodne snage i priroda. Ali to ne znači da na epistemologijskom planu možemo izdvojiti društvene odnose od prirodnih, povijest kapitalizma ne možemo razumjeti kao povijest društva (čovjeka) odijeljenu od prirode, zato za Marxa i postoji samo jedna znanost, "znanost povijesti” (Marx, 1973: 912). U tom je pogledu karakterističan Marxov odnos 
prema Malthusu. Kritički odbacuje njegovu teoriju demografskog rasta i prirodnih ograničenja jer kapitalistički sustav ruše unutrašnji zakoni akumulacije kapitala, a ne vanjska prirodna ograničenja, koja se naposljetku mogu i ukinuti tehnološkim revolucioniranjem "agrikulture". Za Marxa upravo tehnologijski razvoj sadrži aktivan odnos čovjeka spram prirode, razvoj proizvodnih snaga pokazuje središnju ulogu rada, iz čega onda proizlazi proizvodnja ne samo društvenih odnosa nego i kapitala kao proizvodnog odnosa. Tehnologija je pokretačka snaga društvenog razvoja, ali kapitalistička organizacija rada dovodi do eksploatacije, proizvodni odnosi do društvene alijenacije, a i jedno i drugo na kraju šteti i samoj prirodi (Stache, 2017). Nažalost, ni Marx ni Engels nisu posebnu pažnju posvetili njemačkom zoologu Ernstu Haeckelu i njegovoj evolucijskoj morfologiji, raspravi o bazičnoj interakciji organizma i okoliša, adaptaciji čovjeka i prirode (njegov rad o generalnoj morfologiji organizama izašao je u Berlinu godine 1866). Danas je Haeckel poznat kao otac moderne ekologije, dok se Marxa na području Darwinove "ekonomije prirode" više povezuje sa širim pojmom "prirodne povijesti”.

Marxovu poziciju je s tim u vezi želio razotkriti Foster tezom da je "prirodna povijest" zapravo metaodnos čovjeka i prirode, da je upravo prevladavajući utjecaj čovjeka na prirodu pretvorio sadašnju epohu u geološkoj povijesti planeta "holocen" u "antropocen". U antropocenu u posljednjih nekoliko tisuća godina čovjek postaje najvažniji tvorac promjena na Zemlji, a posljedice njegova djelovanja postaju odlučujuće upravo u prijelazu iz agrarne u industrijsku civilizaciju, iz predkapitalističkih društvenih uvjeta u kapitalistički sistem. Foster pitanje ekološke civilizacije želi postaviti polazeći od Marxove koncepcije društvenog razvoja i njegova "metaboličkog odnosa" ljudi i prirode. Marxova "prirodna povijest" znači zapravo tu recipročnu preobrazbu, metamorfozu društvenih i prirodnih promjena, koja u kapitalizmu vodi k ekologijskoj neravnoteži (Foster, 2002; 2017). Kapitalistički proces bezgraničnog rasta, vječite akumulacije kapitala, komodifikacije svih vrsta naprosto nije ekološki održiv. Svaka ekologijska promjena naime stvara nejednakosti u fizičkom prostoru, nejednaka je i redistribucija koristi i troškova u socijalnom sustavu, zato je ekološka nejednakost zapravo samo druga strana društvene nejednakosti, koja utječe na različitu podjelu političke moći. Ekologija je zapravo politika, politička ekonomija postaje politička ekologija.

Ako je kapitalistički sistem počeo ugrožavati cijelu civilizaciju putem ekologijske destrukcije (zagađivanje prirode, klimatske promjene, gubljenje biološke raznolikosti...), onda bismo njegovo razdoblje u razvoju našeg planeta mogli doista nazvati "kapitalocenom" umjesto antropocenom (Moore, 2016). Iz te je perspektive danas ekologijska kritika kapitalizma važnija od tradicionalne političkoekonomske analize, kao što kritičko promišljanje alternativa sadašnjem političkom kapitalizmu sve više postaje projekt ekosocijalizma. Godine 2007. u Parizu je osnovana EIN 
(Ecosocialist International Network), ekosocijalistička internacionala koja želi kroz društvene pokrete i teorijske analize dokazati da ekosocijalizam treba zamijeniti kapitalizam. Marksistički autori, poput O'Connora, govore o različitim protuslovljima kapitalizma, a nasuprot Marxovu osnovnom društvenom proturječju sadržanom u zakonu akumulacije kapitala postavlja se ekologijski problem kao "druga kontradikcija kapitalizma" (O’Connor, 2009). Marksistički usmjerena politička ekologija "politizira" upravo kritiku privatizacije prirodnih resursa i korištenja tržišnih mehanizama u rješavanju globalnih ekologijskih problema (neoliberalna paradigma). Ekologijski uvid postaje novo teorijsko polje novih rješenja starih protuslovlja i problema kapitalizma.

Foster dokazuje da Marxova analiza sadrži i ekologijsku dimenziju, da teorija vrijednosti uzima u obzir prirodne procese, da se povijest prirode i povijest društva neprestance prepleću. S druge strane, O’Connor dokazuje da Marx nije povezivao ekologijska i političkoekonomska pitanja te da marksističku analizu treba primijeniti na ekologijske probleme kapitalocena. U teoriji "metaboličkog procjepa" ekologijska kriza je posljedica kapitalističkog razvoja, jer postoji binarna pozicija priroda - društvo; u konceptualizaciji "druge kontradikcije" kapitalizma ekologijski problem je unutrašnji element kapitalističke akumulacije. Foster i O'Connor žele pokazati kako Marxovi "opći uvjeti proizvodnje" (Grundrisse) impliciraju povezanost ekologijske i političkoekonomske krize. Marxov je teorijski pristup ovdje logičan početak drugačije analize. Kapitalizam proizvodi kapital utoliko ukoliko proizvodi višak vrijednosti, ali kapitalistička akumulacija pritom zahtijeva sve više prirodnih resursa. Problem "metabolizma životne sredine" (Foster) nastaje kada reprodukcija kapitalističkog sistema zahtijeva više resursa nego što ih priroda može ponuditi i kada količina otpada postaje veća od apsorpcijske mogućnosti planeta. Kapitalizam je, prema tome, sistem destrukcije prirode, eksploatacija prirode postaje problematičnija od eksploatacije u okvirima nejednake raspodjele i zbiljske supsumpcije rada pod kapital u proizvodnim odnosima. Ako je politički kapitalizam u određenoj mjeri kroz socijalnu državu i ekonomsku regulaciju ciklusa uspio transformirati kapitalizam i uzdići ga na politički podnošljivu razinu, ekologijske barijere, od komodifikacije prirodnih resursa do neposredne destrukcije prirode (zagađenje, klimatske promjene, pandemije...), dovode do njegovih stvarnih krajnjih granica. Proizvodnja kapitala zapravo je kapitalizacija prirode, kriza kapitalizma nije kriza realizacije (potrošnje), nego kriza troškova (proizvodnje), ekologijska kriza postavlja stvarne granice oplodnji kapitala. U političkom kapitalizmu sadašnjice "metabolizam društvenog sistema" postaje ovisan o "metabolizmu životne sredine".

Ekologijska i ekonomska kriza kapitalizma su dakle međuovisne, ali ostaje pitanje je li ekologijska kriza primarnija od ekonomske ili pak u "kapitalocenu" ekologijska kriza tek proizlazi iz ekonomske. Ako su kapitalizam i priroda dva inkompati- 
bilna entiteta (Foster), s obzirom na to da kapitalistički razvoj nameće ireverzibilnu destrukciju prirode, tada se mora zaključiti da kapitalizam nema budućnosti ne zbog ekonomskih, nego zbog ekologijskih nedostataka (Foster, Clark, York, 2010). Međutim ako je politički kapitalizam sistem koji putem vlastitih preobrazbi može institucionalno preživjeti samo tako da apsorbira sve druge moguće alternative, što onda preostaje kapitalizmu u kapitalocenu kada sistem zbog ekologijskih ograničenja dolazi do svojih stvarnih granica? To je zapravo pravi "kraj povijesti", poslužimo li se Fukuyaminom dojmljivom metaforom, koji se barem na pojmovnoj razini može riješiti samo tako da bezalternativni kapitalizam dobije pravu alternativu - ili ekosocijalizam (Williams, 2010), ili pak da se uspostavi novi politički kapitalizam, više autoritaran nego liberalan, prema tome anti-kapitalizam sa stajališta Fukuyame.

Pandemija Covid-19 dio je tih procesa, globalna kriza 2020. više je nego druge upozorila na granice globalnog kapitalizma, na novu normalu njegove moguće transformacije. Paradoks velikih promjena očito ne leži u geostrategijskim sukobima SAD-a i Kine za dominantan položaj u okviru svjetskog sistema, još manje u traganjima EU-a za novim modelom održivog političkog kapitalizma izvan neoliberalne paradigme, ili pak u globalnim ugovorima o klimatskim promjenama (Pariški sporazum, COP 21), nego u neobičnom spoju pandemijske, političke i ekonomske krize. Između 2010. i 2019. godine WHO nabraja 1483 epidemije u 172 države. U svom izvještaju iz 2018. Svjetska zdravstvena organizacija upozorava da bi zbog pandemijske krize, virusa i patogenih bakterija mogla biti ugrožena trećina svjetskog stanovništva, 50-80 milijuna ljudi moglo bi umrijeti, a ekonomska šteta dosegnuti 5-8\% svjetskog BDP-a... (WHO, 2019). Pandemijski ciklusi mogu biti i češći i brži od velikih dugoročnih političkoekonomskih ciklusa (dugih valova), te su apokaliptični scenariji razvoja kapitalizma vezani uz druge i drukčije činitelje nego što smo do sada mislili.

Virusi određuju granice kapitalizma više nego proizvodni odnosi, nejednaka raspodjela, klimatske promjene i zagađivanje okoliša. Međutim ako se postojeći liberalno-permisivni globalni kapitalizam raspada zbog pandemijske krize, onda je alternativa već tu: barbarski kapitalizam određuju ekstremni politički inženjering političkih elita, redukcija ljudskih i socijalnih prava, digitalni društveni nadzor, žrtvovanje starih ljudi i socijalno ugroženih društvenih grupa... Pandemija je otvorila put političkom kapitalizmu prema novom barbarstvu umjesto prema emancipaciji i mogućoj utopiji globalnog kozmopolitizma, te u kapitalocenu naposljetku postoji izbor između civilizacijskog preživljavanja ili propadanja. Marx je u Komunističkom manifestu postavio taj sudbinski izbor u političkoekonomski kontekst: komunizam ili barbarstvo. Ontologija društvenog bitka kapitalističkog sustava taj izbor sve više potvrđuje kao presudan, pa se pitanje o aktualnosti Marxa 2020. više i ne postavlja, postalo je ekonomski irelevantno i politički neukusno. 


\section{LITERATURA}

Alchian, A., Demsetz, H. (1972) Production, Information Cost, and Economic Organization, American Economic Review (62) 5: 777-795.

Berend, I. T. (2006) Europe in Crisis. Bolt from the Blue?, Routledge, New York.

Bidet, J. (1988) Što da se radi s "Kapitalom"? Materijali za ponovno utemeljenje, Cen$\operatorname{tar}$ CK SKH za idejno-teorijski rad "Vladimir Bakarić", Zagreb.

Bidet, J. (2008) Opća teorija moderne. Teorija prava, ekonomije i politike, Disput, Zagreb.

Coase, R. H. (1960) The Problem of Social Cost, u: The Firm, the Market, and the Law, Chicago UP, Chicago.

Cvijanović, V., Redžepagić, D. (2011) Od političkog kapitalizma do klijentelističkog kapitalizma? Slučaj Hrvatske, Časopis za ekonomsku teoriju i praksu (29) 2: 355-372.

Felton, A., Reinhart, C., ur. (2008) The First Global Financial Crisis of the 21st Century I-II, VoxEU CEPR Publications, London.

Foster, J. B. (2002) Ecology against Capitalism, Monthly Review Press, New York.

Foster, J. B. (2017) Trump in the White House: Tragedy and Farce, Monthly Review Press, New York.

Foster, J. B., Clark, B., York, R. (2010) The Ecological Rift: Capitalisms War on the Earth, NYU Press, New York.

Kindleberger, C. P. (2005) Manias, Panics, and Crashes. A History of Financial Crisis, John Wiley \& Sons, Hoboken.

Kolko, G. (2009) World in Crisis: The End of the American Century, Pluto Press, London.

Korać, M. (1977) Socijalistički samoupravni način proizvodnje I-III (sv. I: 1977, sv. II: 1980, sv. III: 1982), Centar za društvena istraživanja CK SKJ, Beograd.

Kovač, B. (1984) Diskusija, u: Istraživanje socijalističkog samoupravljanja. Politička ekonomija socijalističkog samoupravljanja, Izdavački centar Komunist, Beograd, str. 39-59, 66-71.

Kovač, B. (1988) Način proizvodnje i kritika političke ekonomije, Centar CK SKH za idejno-teorijski rad "Vladimir Bakarić", Zagreb.

Kovač, B. (2009) Uloga novca u metastrukturnoj promjeni tržišnog društva i globalna financijska kriza, Politička misao (46) 3: 105-125.

Kovač, B. (2018) Političko-ekonomski ogledi, NZCGH/Disput, Zagreb.

Lalović, D. (1988) Smisao povratka temeljima "Kapitala", pogovor knjizi u: Bidet, J. (1988), str. 281-306.

Lalović, D. (2008) O autoru i ovom izdanju, pogovor knjizi u: Bidet, J. (2008), str. 341358. 
Lalović, D. (2017) Marxovo nasljeđe kao zadaća mišljenja, pogovor knjizi u: Strpić, D. (2017), str. 439-484.

Lazić, M. (2011) Čekajući kapitalizam, Službeni glasnik, Beograd.

Lerner, A. P. (1972) The Economics and Politics of Consumer Sovereignty, American Economic Review (62), 2: 258-266.

Lewis, H. (2013) Crony Capitalism in America 2008-2012, AC2 Books, Edinburg.

Marx, K. (1973) Kapital. Kritika politične ekonomije, knjiga III, Cankarjeva založba, Ljubljana.

Milanović, B. (2019) Capitalism, Alone: The Future of the System that Rules the World, Belknap Press, Harvard UP, Cambridge MA.

Moore, J. W. (2016) Anthropocen or Capitalocen? Nature, History, and the Crisis of Capitalism, PM Press, Dexter.

O'Connor, M. P. (2009) The second contradiction of capitalism, Capitalism, Nature Socialism, br. 5.

Polanyi, K. (1999) Velika preobrazba. Politički i ekonomski izvori našeg vremena, Naklada Jesenski i Turk, Zagreb (1. izd. 1944; standardno izd. 1957).

Rodrick, D. (2018) Populism and the economics of globalization, Journal of International Business, br. 4.

Sperber, J. (2013) Karl Marx: A Nineteenth-Century Life, Liveright Publishing Corporation, W. W. Norton \& Company, New York.

Stache, C. (2017) Kapitalismus und Naturzerstörung. Zur kritischen Theorie des gesellschaftlichen Naturverhältnisses, Bundrich UniPress, Berlin.

Stedman Jones, G. (2016) Karl Marx: Greatness and Illusion, The Belknap Press, Harvard UP, Cambridge MA.

Stiglitz, J. (2019) People, Power, and Profits: Progressive Capitalism for an Age of Disconsent, W.W. Norton, New York.

Stockman, D. A. (2012) The Great Deformation: The Corruption of Capitalism in America, Public Affairs-Perseus Book Co., New York.

Strpić, D. (2017) Robna proizvodnja i udruženi rad u Marxovoj kritici političke ekonomije, Disput, Zagreb.

Vrousalis, N. (2013) Exploitation, Vulnerability, and Social Domination, Philosophy \& Public Affairs, br. 41, Princeton UP, Princeton, New Yersey.

Williams, C. (2010) Ecology and Socialism: Solution to Capitalist Ecological Crisis, Haymarket Books, Chicago.

WHO (2019) A World at Risk. Annual report on global preparedness for health emergency, GPMB-UN, New York. 


\title{
Bogomir Kovač \\ POLITICAL-ECONOMIC MARGINALIA ON THE RECEPTION OF MARX IN THE XXI CENTURY
}

\begin{abstract}
Summary
In Strpić's book on Marx's critique of political economy, the analysis of political and economic reception of Marx serves as starting point for the author's assignment of contemporary position and relevance of Marx's analysis. Both actualization and return to Marx always occur in the times of crisis, therefore his intellectual fate depends on changes within contemporary capitalism and its alternatives. In Marx's analysis, the paradox of theoretical incompleteness stems from his aim for ideal epistemology of capitalism, which is also present in later Marxist interpretations, even Strpić's. The contemporary problem of Marx lies in the metaphysics of theory of value and in the whole structure of commodity production, which prevents ontological transition of value, capital and capitalism. His approach is physiocratic more than it is pecuniary, and more economic than it is political. This is why Jacques Bidet's reconstruction of Marx in the terms of modernity is based on "metastructure", which is a universal politically legal point that is not present within Marx's critique of political economy. Such a different approach presupposes understanding capitalism as inherently a political project. As it is proven by the author, political capitalism is not a special form of capitalism, nor it is historically connected with contemporary capitalism of the $21^{\text {st }}$ century (in China and elsewhere), but is moreover its universal historical form. Marx's critique of political economy turns out to be contemporary precisely at this overlooked point of his analysis. Political capitalism as "capitalism in general" demonstrates its relevance in the analysis of contemporary crises, which are not just politicaleconomic, but also ecological and even pandemic. In a series of crises of political capitalism we are faced with a choice between real autocratic "barbaric capitalism" and more utopic "cosmopolitan" eco-socialism.
\end{abstract}

Keywords: Capitalism, Commodity Production, Critique of Political Economy, Eco-Socialism, Marx, Strpić

Bogomir Kovač je redoviti profesor na Ekonomskom fakultetu Sveučilišta u Ljubljani na Katedri za ekonomsku teoriju i politiku, Katedri za međunarodnu ekonomiju (pridruženi član) i Katedri za poduzetništvo (pridruženi član).

Kontakt: Bogomir Kovač, Ekonomska fakulteta, Univerza v Ljubljani, Kardeljeva ploščad 17, 1000 Ljubljana. E-mail: bogomir.kovac@ef.uni-lj.si 